\title{
Monoclonal Antibody Protocols
}




\section{Methods in Molecular Biology ${ }^{\text {tm }}$}

\section{John M. Walker, SERIES EDITOR}

45. Monoclonal Antibody Protocols, edited by William C. Davis, 1995

44. Agrobacterium Protocols, edited by Kevan M. A. Gartland and Michael R. Davey, 1995

43. In Vitro Toxicity Testing Protocols, edited by Sheila O'Hare and Chris $\mathrm{K}$. Atterwill, 1995

42. ELISA: Theory and Practice, by John R. Crowther, 1995

41. Signal Transduction Protocols, edited by David A. Kendall and Stephen J. Hill, 1995

40. Protein Stability and Folding, edited by Bret A. Shirley, 1995

39. Baculovirus Expression Protocols, edited by Christopher D. Richardson, 1995

38. Cryopreservation and Freeze-Drying Protocols, edited by John G. Day and Mark R. McLellan, 1995

37. In Vitro Transcription and Translation Protocols, edited by Martin J. Tymms, 1995

36. Peptide Analysis Protocols, edited by Michael W. Pennington and Ben M. Dunn, 1994

35. Peptide Synthesis Protocols, edited by Ben M. Dunn and Michael W. Pennington, 1994

34. Immunocytochemical Methods and Protocols, edited by Lorette C. Javois, 1994

33. In Situ Hybridization Protocols, edited by $\boldsymbol{K} \boldsymbol{H}$. Andy Choo, 1994

32. Basic Protein and Peptide Protocols, edited by John M. Walker, 1994

31. Protocols for Gene Analysis, edited by Adrian J. Harwood, 1994

30. DNA-Protein Interactions, edited by G. Geoff Kneale, 1994

29. Chromosome Analysis Protocols, edited by John R. Gosden, 1994

28. Protocols for Nucleic Acid Analysis by Nonradioactive Probes, edited by Peter G. Isaac, 1994

27. Biomembrane Protocols: II. Architecture and Function, edited by John M. Graham and Joan A. Higgins, 1994

26. Protocols for Oligonucleotide Conjugates, edited by Sudhir Agrawal, 1994

25. Computer Analysis of Sequence Data: Part $I I$, edited by Annette M. Griffin and Hugh G. Griffin, 1994

24. Computer Analysis of Sequence Data: Part $I$, edited by Annette M. Griffin and Hugh G. Griffin, 1994

23. DNA Sequencing Protocols, edited by Hugh G. Griffin and Annette M. Griffin, 1993

22. Optical Spectroscopy, Microscopy, and Macroscopic Techniques, edited by Christopher Jones, Barbara Mulloy, and Adrian H. Thomas, 1994

21. Protocols in Molecular Parasitology, edited by John E. Hyde, 1993

20. Protocols for Oligonucleotides and Analogs, edited by Sudhir Agrawal, 1993

Earlier volumes are still available. Contact Humana for details. 


\title{
Methods in Molecular Biology ${ }^{\prime \prime} \bullet$
}

\section{Monoclonal \\ Antibody Protocols}

\author{
Edited by \\ William C. Davis
}

Department of Veterinary Microbiology and Pathology, College of Veterinary Medicine, Washington State University, Pullman, WA

Humana Press 䅈 Totowa, New Jersey 
C 1995 Humana Press Inc.

999 Riverview Drive, Suite 208

Totowa, New Jersey 07512

All rights reserved.

No part of this book may be reproduced, stored in a retrieval system, or transmitted in any form or by any means, electronic, mechanical, photocopying, microfilming, recording, or otherwise without written permission from the Publisher. Methods in Molecular Biology'm is a trademark of The Humana Press Inc.

All authored papers, comments, opinions, conclusions, or recommendations are those of the author(s), and do not necessarily reflect the views of the publisher.

This publication is printed on acid-free paper. $\infty$

ANSI Z39.48-1984 (American Standards Institute)

Permanence of Paper for Printed Library Materials.

\section{Photocopy Authorization Policy:}

Authorization to photocopy items for internal or personal use, or the internal or personal use of specific clients, is granted by Humana Press Inc., provided that the base fee of US $\$ 4.00$ per copy, plus US $\$ 00.20$ per page, is paid directly to the Copyright Clearance Center at 222 Rosewood Drive, Danvers, MA 01923. For those organizations that have been granted a photocopy license from the CCC, a separate system of payment has been arranged and is acceptable to Humana Press Inc. The fee code for users of the Transactional Reporting Service is: $[0-89603-308-2 / 95 \$ 4.00+\$ 00.20]$.

Printed in the United States of America. 10987654321

Library of Congress Cataloging in Publication Data

Main entry under title:

Methods in molecular biology'm.

Monoclonal antibody protocols / edited by William C. Davis.

p. cm. - (Methods in molecular biologym ; 45)

Includes index.

ISBN 0-89603-308-2 (alk. paper)

1. Monoclonal antibodies-Laboratory manuals. I. Davis, W. C. (William C.) II. Series: Methods in molecular biology ${ }^{\text {tm }}$ (Totowa, NJ); 45.

QR 186.85.M66285 1995

$616.07^{\prime} 93-\mathrm{dc} 20$ 


\section{Preface}

Since the initial description of techniques to immortalize antibody-producing B-lymphocytes by fusion with tissue culture-adapted myeloma cells, methods have been developed to produce monoclonal antibodies of defined specificity in multiple animal species. Stable hybrids can be readily produced in mice using a number of myeloma and hybridoma cell lines. To obviate the problem of identifying fusion partners in other animal species, xenohybrids have been produced using B-lymphocytes from the relevant species and mouse myeloma cells. The use of xenohybrids has minimized the problem of obtaining stable antibody-producing hybrids in all species examined thus far. Although alternative techniques are being developed to produce monoclonal antibodies by molecular methods, hybridoma technology will remain the technology of choice for producing monoclonal antibodies for a variety of applications in research and industry.

The objective of Monoclonal Antibody Protocols is to provide investigators with a set of methods for producing and using monoclonal antibodies in biomedical, agricultural, and biological sciences. The book is not intended to provide methodology for all possible applications, but rather a series of methods presented in an easy-tofollow format that can be used by new and established investigators, graduate and postgraduate fellows, and technical staff. The methods include descriptions of techniques for immunization in vivo and in vitro to obtain the antibodies of interest; production of monoclonal antibodies in mice, humans, and domestic species; isotyping and characterizing antibodies; producing antibodies in a bioreactor to eliminate the need of using mice to produce immune ascites; purification of IgG and IgM antibodies; preparation of immunoaffinity columns; conjugation of antibodies with fluorophores, biotin, and enzymes; and also descriptions of popular applications such as the use of monoclonal antibodies in immunoaffinity purification of mol- 
ecules, Western blotting, and chemiluminescence, immunohistochemistry, electron microscopy, flow cytometry, and magnetic particle separation of leukocyte subpopulations.

Each chapter has been written by an author or authors with considerable experience in the use of the methodology. Where possible, an attempt has been made to introduce recent technological advances that facilitate the development and use of monoclonal antibodies. Each chapter starts with a brief description of the technique and application, followed by a detailed step-by-step outline of the methods. A notes section is included to provide additional information on problems that are occasionally encountered in the use of the technology and recommendations on how to identify the source of the problem and the steps needed to modify the procedures to obtain the expected results. Chapters are cross-referenced where related techniques are described to reduce redundancy and facilitate use of the methodology.

Monoclonal Antibody Protocols should prove effective as an easy-to-use laboratory manual for developing and using monoclonal antibodies.

William C. Davis 


\section{Contents}

Preface

$v$

Contributors $i x$

CH. 1. Methods of Immunization to Enhance the Immune Response

to Specific Antigens In Vivo in Preparation for Fusions

Yielding Monoclonal Antibodies

Jon A. Rudbach, John L. Cantrell, and J. T. Ulrich.

$\mathrm{CH}_{\text {. }}$ 2. Methods of Immunization to Enhance the Immune Response

to Specific Antigens In Vitro

Margaret E. Schelling

CH. 3. Culture Conditions that Optimize Outgrowth of Hybridomas Mary J. Hamilton and William C. Davis.

CH. 4. Production of Stable Heterohybridomas Producing Human

Monoclonal Antibodies

Morris D. Cooper and Risa Kirkpatrick

$\mathrm{CH}_{\mathrm{H}}$. 5. Production of Stable Bovine-Murine Interspecies Hybrids

Brenda V. Jones and Christopher J. Howard.

Сн. 6. Production of Monoclonal Antibodies in Swine

Araceli L. Lumanglas and Bosco Shang Wang 49

CH. 7. Production of Monoclonal Antibodies in Horses

Lance E. Perryman and Patricia H. Mason.

CH. 8. Use of Electric-Field-Mediated Cell Fusion to Produce Hybridomas

Secreting Monoclonal Antibodies

Xi Zhao

Сн. 9. Rapid Isotyping of Mouse Monoclonal Antibodies

Philippe Pouletty

CH. 10. Methods of Measuring Antibodies in Sera/Plasma, Ascites, and Tissue-Culture Media

Jon A. Rudbach, John L. Cantrell, and J. T. Ulrich.

Сн. 11. Measurement of Immunoglobulin Synthesis Using the ELISPOT Assay

Morris D. Cooper and Risa Kirkpatrick.

$\mathrm{CH}_{\mathrm{H}}$ 12. Use of Monoclonal Antibodies in Immunohistochemistry

Shan-Rong Shi, Jeffrey B. Prince, Christopher M. Jones, Krishan L. Kalra, and Atul K. Tandon. 
CH. 13. Use of Monoclonal Antibodies in Immunoelectron Microscopy

Carlos E. Suarez and Ruth Brown

Сн. 14. Use of Monoclonal Antibodies for Western Blotting with Enhanced

Chemiluminescent Detection

Susan J. Fowler.

Сн. 15. The Use of Directly and Indirectly Labeled Monoclonal Antibodies in Flow Cytometry

Carleton C. Stewart and Sigrid J. Stewart.

CH. 16. Use of Monoclonal Antibodies and Flow Cytometry to Cluster and Analyze Leukocyte Differentiation Molecules

William C. Davis, Jennifer E. Davis, and Mary J. Hamilton ... 149

CH. 17. In Vivo and In Vitro Production of Monoclonal Antibodies:

Bioreactors vs Immune Ascites

Uwe Marx and Wolfram Merz.

CH. 18. Separation of Monoclonal Antibodies from Cell-Culture

Supernatants and Ascites Fluid Using Thiophilic Agarose

Thorkild C. Bøg-Hansen.

$\mathrm{CH}$. 19. Detection, Purification, and Utilization of Murine Monoclonal

IgM Antibodies

Ian D. Walker.

Сн. 20. Preparation and Use of Immunoaffinity Columns with Monoclonal

Antibodies Without Purification from Ascites and Tissue-

Culture Medium

Thorkild C. Bøg-Hansen and William C. Davis.

CH. 21. Antigen Purification by Monoclonal Antibody Immunoaffinity

Chromatography

Alberta L. Brassfield.

CH. 22. Coupling of Monoclonal Antibodies with Fluorophores

Rosaria P. Haugland.

Cн. 23. Coupling of Monoclonal Antibodies with Biotin

Rosaria P. Haugland and Wendy W. You

Сн. 24. Coupling of Monoclonal Antibodies with Enzymes

Rosaria P. Haugland.

CH. 25. Use of Monoclonal Antibodies with Magnetic Particles to Separate

Cell Subpopulations by Negative Selection

Dennis E. Vaccaro and Joan E. Markinac. 245

Сн. 26. Use of Monoclonal Antibodies with Magnetic Particles to Separate

Cell Subpopulations by Positive Selection

Dennis E. Vaccaro and Joan E. Markinac. 253

Index 


\section{Contributors}

Thorkild C. Bøg-Hansen • The Protein Laboratory, The Panum Institute, University of Copenhagen, Denmark

AlbeRTA L. BRASSFIELD - Department of Veterinary Microbiology and Pathology, College of Veterinary Medicine, Washington State University, Pullman, WA

RUTH BROWN • Department of Veterinary Microbiology and Pathology, College of Veterinary Medicine, Washington State University, Pullman, CA

JohN L. CANTRELL • RIBI ImmunoChem Research, Inc., Hamilton, MT

MORRIS D. COOPER - Department of Medical Microbiology and Immunology,

Southern Illinois University School of Medicine, Springfield, IL

JenNIFER E. Davis • Fred Hutchinson Cancer Research Center,

Seattle, WA

WILLIAM C. DAVIS • Department of Veterinary Microbiology

and Pathology, College of Veterinary Medicine, Washington

State University, Pullman, WA

SUSAN J. FOWLER • Amersham International, Amersham, Bucks, UK

MARY J. HAMILTON • Department of Veterinary Microbiology

and Pathology, College of Veterinary Medicine, Washington

State University, Pullman, WA

Rosaria P. Haugland $\bullet$ Molecular Probes Inc., Eugene, OR

CHRISTOPHER J. HOWARD - Institute for Animal Health, Compton

Laboratory, Berkshire, UK

BRENDA V. Jones - Institute for Animal Health, Compton Laboratory, Berkshire, UK

Christopher M. Jones $\bullet$ BioGenex, San Ramon, CA

Krishan L. KalRa $\bullet$ BioGenex, San Ramon, $C A$

RISA KIRKPATRICK • Department of Medical Microbiology

and Immunology, Southern Illinois University School

of Medicine, Springfield, $I L$ 
ARACELI L. LUMANGLAS • Laboratory of Immunoendocrinology, Agricultural Research Division, American Cyanamid Company, Princeton, $N J$

JoAn E. MarkInAC • PerSeptive Diagnostics, Inc., Cambridge, MA UwE MARX • Institute for Medical Immunology, Charité University Clinic, Medical Faculty of Humboldt University, Berlin, Germany

Patricia H. Mason - Department of Veterinary Microbiology and Pathology, College of Veterinary Medicine, Washington State University, Pullman, WA

WOLFRAM MERZ • Integra Biosciences, Inc., Woburn, MA

LANCE E. PERRYMAN • College of Veterinary Medicine, North

Carolina State University, Raleigh, NC

Philippe Pouletty - SangStat Medical Corp., Menlo Park, CA

JefFrey B. Prince • BioGenex, San Ramon, CA

Jon A. RUDBACH • RIBI ImmunoChem Research, Inc., Hamilton, MT

Margaret E. Schelling - Program in Genetics and Cell Biology,

Washington State University, Pullman, WA

Shan-Rong ShI • BioGenex, San Ramon, CA

Carleton C. Stewart • Laboratory of Flow Cytometry, Roswell Park

Cancer Institute, Buffalo, NY

Sigrid J. STEWART • Laboratory of Flow Cytometry, Roswell Park

Cancer Institute, Buffalo, $N Y$

Carlos E. SuARez • Department of Veterinary Microbiology

and Pathology, College of Veterinary Medicine, Washington

State University, Pullman, CA

Atul K. TANDON • BioGenex, San Ramon, CA

J. T. ULRICH • RIBI ImmunoChem Research, Inc., Hamilton, MT

Dennis E. VaCCARo - PerSeptive Diagnostics, Inc., Cambridge, MA

IAN D. WALKER - School of Veterinary Medicine, Veterinary Preclinical

Centre, University of Melbourne, Parkville, Victoria, Australia

Bosco Shang W ANG - Laboratory of Immunoendocrinology,

Agricultural Research Division, American Cyanamid Company,

Princeton, $N J$

Ana WeImin You - Molecular Probes Inc., Eugene, OR

$\mathrm{XI}$ ZHAO $\bullet$ InCell Inc., Santa Clara, CA 